Review Article

\title{
The Therapeutic Potential of Inflamed Gingiva-Derived Mesenchymal Stem Cells in Preclinical Studies: A Scoping Review of a Unique Biomedical Waste
}

\author{
Gamilah Al-Qadhi $\left(\mathbb{D},{ }^{1}\right.$ Sarah Al-Rai $\left(\mathbb{D},{ }^{2}\right.$ and Layla Hafed $\mathbb{D}^{3}$ \\ ${ }^{1}$ Department of Basic Dental Sciences, Faculty of Dentistry, University of Science and Technology, Yemen \\ ${ }^{2}$ Department of Conservative and Preventive Dentistry, Faculty of Dentistry, Saba University, Yemen \\ ${ }^{3}$ Department of Oral Pathology, Faculty of Oral and Dental Medicine, Ahram Canadian University, Giza, Egypt \\ Correspondence should be addressed to Gamilah Al-Qadhi; gamilah.alqadhi@dentistry.cu.edu.eg
}

Received 8 November 2020; Revised 8 January 2021; Accepted 27 January 2021; Published 10 February 2021

Academic Editor: Manuel Scimeca

Copyright (C) 2021 Gamilah Al-Qadhi et al. This is an open access article distributed under the Creative Commons Attribution License, which permits unrestricted use, distribution, and reproduction in any medium, provided the original work is properly cited.

\begin{abstract}
Searching for considerable abundance, simple, and accessible sources in stem cell-based therapy opens the door for isolation of a new population of oral/dental stem cells known as inflamed gingiva-derived mesenchymal stem cells, which have recently come to light with promising therapeutic potential in tissue regenerative therapy. Following the Preferred Reporting Items for Systematic reviews and Meta-Analyses extension for Scoping Reviews guidelines, this scoping review is aimed at highlighting the possible therapeutic potential of inflamed gingiva-derived mesenchymal stem cells in preclinical studies carried out to date and presenting the current evidence depends upon their comparison to the healthy gingiva-derived mesenchymal stem cells or other mesenchymal stem cell sources. A comprehensive electronic search using (PubMed, Embase, Scopus, and Web of Science) databases and a manual search of relevant references were conducted until June 2020. Included studies were assessed using a combination tool, including the guidelines for reporting preclinical in vitro studies on dental materials, which were based on the modification of the Consolidated Standards of Reporting Trial checklist and the guidelines for animal research: reporting of in vivo experiments. The initial research provided 360 articles, with 13 articles that met the inclusion criteria. While most of the included studies lacked randomization, blinding, and sample size calculation, they were designed accurately in other aspects of the guidelines. The results of this scoping review indicated that inflamed gingiva-derived mesenchymal stem cells could be effective in terms of osteogenic differentiation, collagen fiber formation, immunoregulation, migration capacity, and testing of dental material and may present a reliable alternative source for healthy gingiva-derived mesenchymal stem cells.
\end{abstract}

\section{Introduction}

Stem cell-based therapy has attracted many researchers in the regenerative medicine field, primarily mesenchymal stem cells (MSCs), which play a fundamental role with the surrounding microenvironment during the regenerative process [1]. Bone marrow and adipose tissues are the most commonly used sources. However, the associated invasive surgical procedure for both patient and donor opens the door to look for easily accessible and less invasive alternative sources. The discovery of prevalent cells having the typical characteristics of MSCs in the oral cavity has made scientists become more interested in oral tissues. Oral-derived mesenchymal stem cells can be easily isolated from diverse sources, including dental pulp of permanent teeth or exfoliated deciduous teeth, periodontal ligaments, dental follicle, apical papilla, and alveolar bone. These cells displayed great plasticity towards trilineages, particularly towards the osteogenic lineage [2].

Moreover, gingival mesenchymal stem cells (GMSCs) are one of these doors denoting the recent newly identified population from dental/oral tissue. In several studies, mesenchymal stem cells isolated successfully from gingiva and met the minimal criteria proposed by the International Society for 
Cellular Therapy (ISCT) for MSCs' characterization. Human GMSCs showed self-renewal capabilities via the formation of colony-forming units (CFU), trilineage differentiation ability into osteoblast, adipocyte, and chondrocyte cell lineage under in vitro culture condition and expression of MSC markers and stem cell-specific genes [3-5].

Interestingly, the discarded diseased gingival tissue might represent a possible valid alternative source to healthy ones. Mesenchymal stem cell-like population obtained from inflamed gingival tissue had similar functional properties to the GMSCs isolated from healthy tissue. The trilineage differentiation capacity and surface marker expression were similar in both populations. Additionally, ectopic transplantation of stem cells from both sources resulted in the formation of a connective tissue-like structure similar to natural gingiva. However, the doubling time was declined in GMSCs derived from inflamed tissue $[6,7]$.

Likewise, other MSCs of inflamed dental origin were successfully isolated and characterized, and the MSCs isolated from inflamed gingiva and dental pulp tissues displayed a higher proliferation rate than the healthy control. Particularly, proinflammatory cytokines such as interleukin-1 $\beta$ (IL-1 $\beta$ ) and tumor necrosis factor- $\alpha$ (TNF- $\alpha$ ) promoted the expansion of both sources in vitro culture. The osteogenic markers were significantly higher in proinflammatory cytokine-treated dental pulp or gingival tissue in comparison to their untreated healthy ones. Clearly, the inflammatory environment did not change MSC markers or numbers neither osteogenic differentiation [8]. Further, the differentiation capacity of GMSCs and periodontal ligament mesenchymal stem cells (PDLSCs), whether derived from healthy or diseased periodontal ligament tissues, was similar [9].

On the contrary, another study stated that MSCs derived from inflamed periodontal ligament exhibited impaired immunomodulatory function and immune response via inhibition of $\mathrm{T}$ cell proliferation along with enhancement of osteoclastogenesis and alveolar bone loss in periodontitis, while cells obtained from healthy tissues showed the normal profile [10].

Furthermore, when GMSCs and PDLSCs were cultured in an osteogenic induction medium supplemented with TNF- $\alpha$ and IL- $1 \beta$ to create an inflammatory microenvironment, both cells displayed a decline in the formation of mineralized nodules, alkaline phosphatase (ALP) activity, and expression of the following osteogenic markers: osteocalcin (OCN), runt-related transcription factor 2 (RUNX2), and collagen type 1 (COL1) [11].

Recently, GMSCs from healthy and inflamed tissue were loaded on microperforated membranes to evaluate their proliferation and migration capacity. The finding revealed that both sources are functionally and phenotypically characterized as MSCs. Notably, the proliferation rate was significantly higher in inflamed GMSCs. Concerning the migration dynamics, GMSCs whether from healthy or inflamed tissues exhibited a similar migration pattern toward chemoattractant through smaller pore sizes. It is worth noting that a better migratory activity was reported in GMSCs derived from healthy tissues in the case of large pore-sized membrane [12].
Similarly, the type of scaffold could play a critical role in cell growth and lineage direction. For example, GMSCs obtained from diseased tissue and seeded on two types of the scaffold, nano hydroxyapatite (HA) and collagen type 1, revealed that collagen type 1 scaffold supported growth and osteodifferentiation of GMSCs more than a nano HA [13]. In addition to the self-renewal, multipotent differentiation and migration capacity, which collectively represent one of the GMSC mechanisms in the regenerative approach, GMSCs have significant immunomodulatory and anti-inflammatory functions. The latter mechanism is mediated through suppression of inflammatory infiltrates and proinflammatory cytokines, induction of immunosuppressive factors such as IL10 , and increased infiltration of regulatory T cells [3]. Along with that, GMSCs promoted polarization of macrophages toward the anti-inflammatory M2 phenotype via increased expression of IL-10 and decreased expressions of IL-6 and TNF- $\alpha[14]$.

Additionally, Toll-like receptors (TLRs) may be responsible for cross talk between GMSCs and their inflammatory environment. Fawazy El-Sayed et al. [15] investigated the TLR expression profile of GMSCs in healthy and diseased conditions. The results showed that GMSCs cultured in basic medium expressed the following TLRs: 1, 2, 3, 4, 5, 6, 7, and 10, while those cultured in medium supplemented with inflammatory cytokines like IL- $1 \beta$, interferon- $\gamma$ (IFN- $\gamma$ ), TNF- $\alpha$, and IFN- $\alpha$ significantly expressed TLRs $1,2,4,5$, and 7 as well as 10 without TLR 6 . This expression may determine the therapeutic potential of GMSCs in recognizing the pathway of pathogen-associated molecular patterns (PAMPs) in periodontal disease.

GMSCs regardless of their origin (healthy or inflamed gingival tissue) exhibited immunoregulatory functions, particularly immunosuppression, in a mouse skin allograft model through upregulation of putative systemic regulatory T cells (Tregs) [6]. On the contrary, MSCs derived from inflamed gingiva revealed impaired stemness and deficient immunomodulatory function. Fortunately, this deficiency could be rescued by pretreatment of inflamed GMSCs culture with acetylsalicylic acid (ASA), a type of nonsteroidal antiinflammatory drug (NSAID), which was able to increase the expression of Fas Ligand (FasL) and, in turn, induce T cell apoptosis [16]. Overall, the finding of I-GMSCs is a significant step in tissue regeneration as the existence of gingival tissue within a microenvironment characterized by constant bacterial challenges and inflammatory changes. In addition to that, their ability to resist these changes with maintaining their MSC's features opens the door for the possibility of using this source in the in vivo regenerative applications, where similar inflammatory factors are involved in a regenerative process [17].

The initial inflammation in the periodontal tissues is a physiologic rather than a pathological mechanism, and it is mainly characterized by plaque formation [18]. Although the oral rinses have antiplaque and antimicrobial actions against plaque accumulation [19], their effects on osteoblast precursors should be taken into consideration. In in vitro study, mouth rinses inhibited cell viability and changed the morphology of osteoblastic precursor cells regardless of their 
type, duration, or alcohol content. However, this finding was limited and not sufficient to give evidence since it was confined to a laboratory environment, and further in vivo studies and clinical trials are required to assess the safety of oral rinse on various progenitor cells [20].

Inflammatory microenvironments that characterize different oral pathologies such as periodontitis and periapical cyst have shown that they are capable of modifying the characteristic of MSCs and even enhancing them in certain cases. For instance, MSCs obtained from human periapical cysts exhibited similar features to oral-/dental-derived MSCs such as high proliferative rate and extensive multipotency which makes them a potential source in regenerative medicine [21].

Stem cells isolated from the discarded gingival tissue have received much attention over recent years. The effectiveness of any intervention should be excessively examined in preclinical studies before translating into a clinical setting. To date, there was no available scoping review mapping the effectiveness of inflamed gingiva-derived mesenchymal stem cells in the tissue regenerative field. Therefore, the purpose of the current scoping review was to present what is known from the previous literature about the therapeutic role of inflamed GMSCs and certainly addressed the following question: To what extent would I-GMSCs be considered as an alternative approach for MSCs derived from healthy tissue in preclinical studies? The PICO relevant key elements were set as follows: population, in vitro cultures and animal studies; intervention, inflamed GMSCs; control or comparator, control: healthy GMSCs or other healthy MSC sources and/or comparator: other inflamed MSC sources; outcome, therapeutic potential.

\section{Materials and Methods}

The current scoping review was conducted following the Preferred Reporting Items for Systematic reviews and MetaAnalyses extension for Scoping Reviews (PRISMA-ScR) guidelines [22].

2.1. Protocol Registration. he protocol was registered with the Open Science Framework for scoping review protocol registration on 15 September 2020 at the following link: https://osf.io/ jt62m and registration DOI: 10.17605/OSF.IO/JT62M.152.

2.2. Eligibility Criteria. The following articles, regardless of their outcome measures, were selected to be included in the current scoping review: (a) original experimental studies comparing GMSCs from the diseased tissue versus those isolated from healthy ones or those obtained from other MSC sources, (b) studies that treated GMSCs with proinflammatory cytokines in culture versus untreated cells, and (c) preclinical studies (in vitro or in vivo) and there was no language or date restrictions. On the other hand, nonexperimental articles such as reviews, case reports, and expert opinions were excluded during the first phase of screening. Further, studies using derivatives of inflamed GMSCs, such as exosomes or microvesicles, and studies that applied genetic modification were excluded during the second phase of screening. The materials and methods section should con- tain sufficient detail so that all procedures can be repeated. It may be divided into headed subsections if several methods are described.

2.3. Information Sources and Search Strategy. In June 2020, four electronic databases (PubMed, Embase, Scopus, and Web of Science) were searched without any date or language restrictions. Key terms such as inflamed gingiva OR diseased gingiva $\mathrm{OR}$ discarded gingiva $\mathrm{OR}$ hyperplastic gingiva derived mesenchymal stem cells $\mathrm{OR}$ inflammation-derived gingival stem cells were initially used and resulted in a few retrieved papers. Therefore, a combination of keywords and index term keywords was expanded to include the following items: inflammation OR inflamed OR diseased OR discarded OR hyperplastic AND gingival mesenchymal stem cell OR gingiva derived mesenchymal stem cell OR gingival tissuederived mesenchymal stem cells OR gingiva derived stromal cell OR multipotent gingival stromal cell OR multipotent gingiva progenitor cell OR gingiva stem cells AND animal model OR experimental animal OR laboratory animal OR in vivo study $\mathrm{OR}$ in vitro study $\mathrm{OR}$ in vitro $\mathrm{OR}$ in vitro technique OR cell culture technique OR cell culture method OR culture technique OR preclinical study. The search strategy for each database was documented, and the retrieved references were combined and saved in one Mendeley folder. Then, duplicate records were removed.

2.4. Selection of Sources of Evidence. The selection of studies was carried out independently through two phases by two authors (Al-Qadhi and Hafed). First, the title and abstract of retrieved papers were screened to identify potentially eligible papers. References that did not fulfill the inclusion criteria were excluded. Second, full-text articles were screened in detail to assess and decide which study was appropriate for inclusion. Any disagreement in study selection was resolved by discussion, and the third author (Al-Rai) asked for her opinion. Reasons for exclusion were identified and documented.

2.5. Data Charting Process and Data Items. All authors participated in the process of designing the initial table and determining the data items. Data from the relevant studies were charted into a predesigned table by one author (AlQadhi) and then checked by two authors (Hafed and AlRai). Similar to the previous step, any disagreement in data entry was resolved by discussion with team members. The following items were extracted: study ID (author and year of publication), characteristics of methodology (study design; in vitro or in vivo, source of stem cells, sample collection, experimental sets or groups, scaffold, or carrier if present), and results of the included studies (clonogenic ability, population doubling capacity, phenotypic profile, differentiation profile, outcome measures, method of investigation, and endpoint).

2.6. Critical Appraisal of Individual Sources of Evidence. The quality assessment of included studies was carried out independently by (Al-Qadhi and Al-Rai). It should be noted that there is not a defined grading quality scale for preclinical studies, particularly in vitro studies. The experimental design 
of all included studies was in vitro or in vitro followed by in vivo (ectopic confirmation). Therefore, guidelines for reporting preclinical in vitro studies on dental materials, which based on the modification of the Consolidated Standards of Reporting Trial (CONSORT) checklist [23], and the guidelines for Animal Research: Reporting of In Vivo Experiments (ARRIVE) were applied with some modification for quality assessment of included studies [24].

The grading system had two forms of responses. The first form was as follows: clearly inadequate, possibly accurate, and clearly accurate responses, which were scored with (1), (2), and (3), respectively; the second form was yes or no, which were scored with (0) and (1). The rating of overall quality was as follows: 1-9: low, 10-19: moderate, and 2029: high for in vitro studies and 1-12: low, 13-24: moderate, and 25-38: high for in vitro followed by in vivo studies.

2.7. Synthesis of Results. The findings of the current research were summarized and presented in a tabular and textual qualitative manner. Meta-analysis was not applicable in the scoping review.

\section{Results}

3.1. Selection of Sources of Evidence. A total of 359 citations was identified from the defined electronic databases (PubMed $=181$, Embase $=25$, Scopus $=143$, and Web of Science $=10$ ), and one additional relevant article was detected through the manual search. After removing duplicate records, 260 papers were identified and subjected to the first level of screening (titles and abstracts) in which 240 irrelevant papers were excluded.

At the second level of screening (full texts), the remaining 20 articles were screened further and assessed for eligibility. Of these, seven articles were excluded as they did not meet the inclusion criteria. In detail, one study used stem cells from inflamed periodontal ligaments, not from the gingiva [9], one study did not use the inflamed gingival source (irrelevant intervention) [25], and one study used inflammatory cytokine-treated cells without untreated or healthy control groups [26]. Correspondingly, three studies used extracellular vesicles or external factors including microvesicles [27], epigenetic modification [28], and Retinol [29], as well as one study used stem cells obtained from healthy gingiva in an inflammatory animal model [30]. Thus, 13 studies were included in the current scoping review (Figure 1).

3.2. Characteristics of Sources of Evidence. The characteristics and the results of the included studies are reported in Tables 1 and 2, respectively. The included studies were published between 2011 and 2020. The experimental design of all studies was in vitro $[6-8,11-13,15,16,31-35]$, and five of these were used in vivo models for further assessment $[6,7$, $11,16,32]$. All studies used the human as MSC source except one study used mice [16].

The majority of studies provided information about the diseased tissue sampling, while one article did not report the details [12]. MSCs from diseased gingiva were collected, whether directly during the gingivectomy proce- dure, extraction of periodontally affected teeth, and flap debridement $[6-8,13,31,32,35]$ or indirectly via inflammatory preconditioned culture. In particular, GMSCs were treated with a culture containing inflammatory cytokines such as TNF- $\alpha$, IL- $1 \beta$, IFN- $\gamma$, IFN- $\alpha$, and IL-3 $[11,12,15$, 33 , and an inflammatory animal model was created in one study, ligature-induced periodontitis in mice [16]. Regarding the healthy source, MSCs from healthy gingiva were obtained during the normal dental processes such as crown lengthening procedure and extraction of third molars due to impaction or orthodontic treatment.

In detail, five studies used H-GMSCs versus I-GMSCs $[12,13,16,31,35]$, and two studies compared H-GMSCs with I-GMSCs as well as bone marrow mesenchymal stem cells (BMSCs) [6] or PDLSCs [7]. Further, two articles compared inflammatory cytokine-treated H-GMSCs with untreated ones $[15,33]$, and two studies compared inflammatory cytokine-treated H-GMSCs to untreated ones, as well as inflammatory cytokine-treated BMSCs and adiposederived stem cells (ADSCs) [31], PDLSCs [11], and dental pulp stem cells (DPSCs) $[8,32]$.

The majority of studies performed several assessments regarding the characteristic of interventions, including clonogenic potential, proliferation rate, phenotypic profile, and functional differentiation (osteogenic, adipogenic, and chondrogenic $[6,7,12,16,35]$, osteogenic and adipogenic $[31,32]$, and osteogenic [13]) for MSCs derived from both healthy and diseased gingival tissue. Three studies performed the characterization for MSCs derived from healthy tissue only $[11,15,33]$, and one article did not conduct any MSC characterization assays [31] (Table 2).

A variety of outcomes in terms of the therapeutic potential of inflamed gingiva-derived MSCs was reported using appropriate methods of investigation. It should be noted that some studies have more than one outcome. These outcomes included osteogenic potential $[8,11,13,31-33]$, migration capacity $[12,34]$, formation of collagenous tissue $[6,7,32]$, testing biocompatibility of resin composite [32], immuneregulation including TRL expressions [15], immunomodulation [6], and inflammatory receptor expression [31].

3.3. Critical Appraisal within Sources of Evidence. Overall, most of the included studies provided adequate information about abstract, background, objectives, the ethical approval, study design, experimental groups, result and its interpretation, outcome evaluation, statistical method, funding source, conflict of interest, and peer-review publication, following the items of the appropriate guideline. However, the majority of them lacked sample size calculation and provided incomplete details about replication, randomization, and blinding. All studies, with the exception of study conducted by Tomasello et al. [8], did not explain any excluded data, such as how many samples processed successfully or unsuccessfully due to bacterial contamination or other factors?. For in vivo part, none of the included studies stated the required information about 289 housing, husbandry conditions, the baseline characteristics, and the health status of animals. The quality of the in vitro and in vivo studies selected in this scoping review is shown in supplementary material I. 


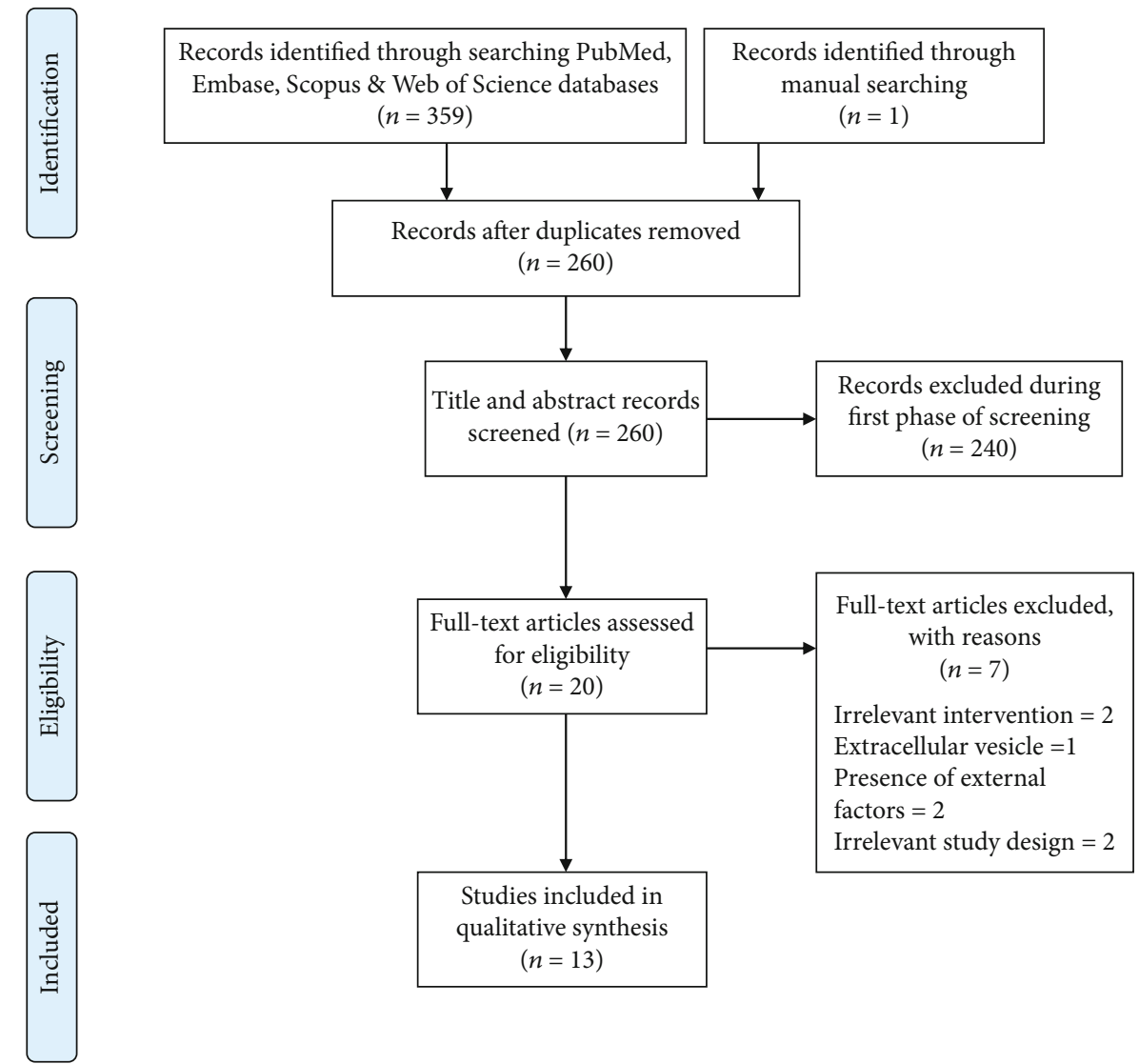

FIGURE 1: Flow diagram showing the different phases of literature screening for the scoping review process. (Editable file: PRISMA Flow Diagram, Liberati et al., 2009).

\subsection{Results of Individual Sources of Evidence}

3.4.1. Clonogenic, Proliferation, and Population Doubling Capacities. The clonogenic ability of I-GMSCs was higher than H-GMSCs in four studies $[6,8,13,31]$, lower in two studies $[16,33]$, and no significant difference between the two sources in three studies [7, 12,32]. Likewise, the proliferation capacity of I-GMSCs was faster than H-GMSCs in four studies $[7,8,13,32]$ and lower in two studies $[16,33]$, and four articles reported that both I-GMSCs and H-GMSCs exhibited an increase in proliferation rate, somewhat similar to each other $[6,12,31,35]$. It should be mentioned that two studies carried out the previous analysis for healthy tissue only $[11,15]$, and another two studies did not do this investigation at all $[34,35]$. In the light of doubling population capacity, I-GMSCs were higher than H-GMSCs in four studies $[6,8,12,13]$ and shorter in two studies $[7,16]$. The remaining studies did not conduct this assay (Table 2).

3.4.2. MSC Characterization. Concerning the specific features of MSCs, both I-GMSCs and H-GMSCs had typical MSCassociated surface markers, a similar positive expression for MSC markers STRO-1, CD29, CD44, CD90, CD105, and CD146 and negative for CD34 and CD45 in six studies [6, $7,12,32-34]$. However, two studies reported higher expression of positive markers in diseased groups than healthy con- trols $[8,13]$, while one study stated the opposite [16]. Similarly, in five articles, both I-GMSCs and H-GMSCs had a similar trilineage differentiation capacity: osteogenic, chondrogenic, and adipogenic $[6,7,12,35]$ and osteogenic differentiation only [13]. Different capacity was reported in four articles, in which I-GMSCs showed lower osteogenic and adipogenic capacities $[16,32]$ and decline osteogenic potential [11], and H-GMSCs had higher osteogenicity, while IGMSCs had a higher adipogenesis [33] (Table 2).

3.4.3. Main Findings of the Outcome. The following outcomes reported in the selected studies are as follows:

(1) Osteogenic Differentiation. Six of the included studies showed that I-GMSCs had potential osteogenic differentiation $[8,11,13,31-33]$. More specifically, inflammatory cytokine-treated H-DPSCs and H-GMSCs as well as IGMSCs were deeply stained and highly expressed osteogenic markers than untreated H-MSCs [8]. Although both cell sources had a tendency toward osteogenic differentiation, H-GMSCs had higher osteogenicity, while I-GMSCs showed increased adipogenesis [33]. Likewise, both sources showed a moderate expression of osteogenic markers (RUNX2, OCN, and osteopontin $(\mathrm{OPN})$ ) [13]. It is worth noting that the selective anti-inflammatory intervention could enhance osteogenic differentiation of GMSCs [35]. 
TABLE 1: Characteristics and methodologies of included studies.

\begin{tabular}{|c|c|c|c|c|c|c|c|c|c|}
\hline \multirow[b]{2}{*}{ No. } & \multirow[b]{2}{*}{ Study ID } & \multirow[b]{2}{*}{$\begin{array}{l}\text { Study } \\
\text { design }\end{array}$} & \multirow[b]{2}{*}{$\begin{array}{l}\text { GMSC } \\
\text { source }\end{array}$} & \multicolumn{2}{|c|}{ Sample collection } & \multicolumn{3}{|c|}{ Experimental design } & \multirow[b]{2}{*}{$\begin{array}{l}\text { Scaffold or carrier } \\
\text { (if present) }\end{array}$} \\
\hline & & & & Healthy & Diseased & $\begin{array}{l}\text { Source of } \\
\text { interest }\end{array}$ & $\begin{array}{l}\text { Other sources } \\
\text { (if present) }\end{array}$ & Control & \\
\hline 1 & $\begin{array}{l}\text { Tang et al., } \\
2011[6]\end{array}$ & $\begin{array}{l}\text { In vitro } \\
\text { \& in vivo }\end{array}$ & Human & Not specified & $\begin{array}{l}\text { Gingivectomy due } \\
\text { to drug-induced } \\
\text { gingival hyperplasia }\end{array}$ & I-GMSCs & - & $\begin{array}{l}\text { H-GMSCs } \\
\text { H-BMSCs } \\
\text { (in vivo) }\end{array}$ & $\begin{array}{c}\text { Subcutaneous } \\
\text { transplantation of } \\
\text { stem cells loaded on } \\
\text { fibrin gel }\end{array}$ \\
\hline 2 & $\begin{array}{c}\text { Ge et al., } 2012 \\
\text { [7] }\end{array}$ & $\begin{array}{l}\text { In vitro } \\
\text { \& in vivo }\end{array}$ & Human & $\begin{array}{c}\text { Crown } \\
\text { lengthening } \\
\text { procedure }\end{array}$ & $\begin{array}{c}\text { Flap debridement } \\
\text { in chronic } \\
\text { periodontitis }\end{array}$ & I-GMSCs & - & $\begin{array}{l}\text { H-GMSCS } \\
\text { H-PDLSCs } \\
\text { (in vivo) }\end{array}$ & $\begin{array}{l}\text { Subcutaneous } \\
\text { transplantation of } \\
\text { stem cells mixed } \\
\text { with HA/TCP } \\
\text { powder }\end{array}$ \\
\hline 3 & $\begin{array}{c}\text { Li et al., } 2013 \\
{[34]}\end{array}$ & $\begin{array}{l}\text { In vitro } \\
\text { \& in vivo }\end{array}$ & Human & Not specified & $\begin{array}{l}\text { Gingivectomy due } \\
\text { to dental plaque- } \\
\text { induced gingival } \\
\text { hyperplasia } \\
\text { (in vitro) } \\
\text { Cells were treated } \\
\text { with culture } \\
\text { containing } \\
\text { inflammatory } \\
\text { cytokines TNF- } \alpha \\
\text { and IL-1 } \beta \text { (in vivo) }\end{array}$ & $\begin{array}{l}\text { I-GMSCs } \\
\text { (in vitro) } \\
\text { Inflammatory } \\
\text { cytokine- } \\
\text { treated } \\
\text { HGMSCs } \\
\text { (in vivo) }\end{array}$ & $\begin{array}{l}\text { Inflammatory } \\
\text { cytokine- } \\
\text { treated } \\
\text { HDPSCs } \\
\text { (in vivo) }\end{array}$ & $\begin{array}{l}\text { H-GMSCs } \\
\text { H-DPSCs }\end{array}$ & $\begin{array}{l}\text { Subcutaneous } \\
\text { transplantation of } \\
\text { stem cell sheets }\end{array}$ \\
\hline 4 & $\begin{array}{l}\text { Yang et al., } \\
2013 \text { [11] }\end{array}$ & $\begin{array}{l}\text { In vitro } \\
\text { \& in vivo }\end{array}$ & Human & $\begin{array}{l}\text { Extraction of } \\
\text { third molars }\end{array}$ & $\begin{array}{l}\text { Cells were treated } \\
\text { with culture } \\
\text { containing } \\
\text { inflammatory } \\
\text { cytokines TNF- } \alpha \\
\text { and IL- } 1 \beta \\
\end{array}$ & $\begin{array}{l}\text { Inflammatory } \\
\text { cytokine- } \\
\text { treated } \\
\text { HGMSCs }\end{array}$ & $\begin{array}{l}\text { Inflammatory } \\
\text { cytokine- } \\
\text { treated } \\
\text { HPDLSCs }\end{array}$ & $\begin{array}{l}\text { H-GMSCS } \\
\text { H-PDLSCs }\end{array}$ & $\begin{array}{c}\text { Subcutaneous } \\
\text { transplantation of } \\
\text { stem cell loaded on } \\
\text { artificial bone repair } \\
\text { materials (iliac } \\
\text { Golden }{ }^{\circledR} \text { ) }\end{array}$ \\
\hline 5 & $\begin{array}{c}\text { Fawzy } \\
\text { El-Sayed et al., } \\
2016 \text { [15] }\end{array}$ & In vitro & Human & $\begin{array}{l}\text { Free gingival } \\
\text { collar }\end{array}$ & $\begin{array}{l}\text { Cells were treated } \\
\text { with culture } \\
\text { containing } \\
\text { inflammatory } \\
\text { cytokines TNF- } \alpha \text {, } \\
\text { IL- } 1 \beta \text {, IFN- } \gamma \text {, and } \\
\text { IFN- } \alpha\end{array}$ & $\begin{array}{l}\text { Inflammatory } \\
\text { cytokine- } \\
\text { treated } \\
\text { HGMSCs }\end{array}$ & - & H-GMSCS & Culture medium \\
\hline 6 & $\begin{array}{l}\text { Barhanpurkar- } \\
\text { Naik et al., } \\
2017 \text { [31] }\end{array}$ & $\begin{array}{l}\text { In vitro } \\
\text { and } \\
\text { in vivo }\end{array}$ & Human & Not specified & $\begin{array}{l}\text { Cells treated with } \\
\text { inflammatory } \\
\text { cytokine IL-3 }\end{array}$ & $\begin{array}{c}\text { Inflammatory } \\
\text { cytokine- } \\
\text { treated H- } \\
\text { GMSCs }\end{array}$ & $\begin{array}{l}\text { Inflammatory } \\
\text { cytokine- } \\
\text { treated } \\
\text { HBMSCs and } \\
\text { H-ADSCs } \\
\end{array}$ & $\begin{array}{l}\text { H-GMSCs } \\
\text { H-BMSCs } \\
\text { H-ADSCs }\end{array}$ & Culture medium \\
\hline 7 & $\begin{array}{l}\text { Tomasello } \\
\text { et al., } 2017 \text { [8] }\end{array}$ & In vitro & Human & $\begin{array}{l}\text { Extraction of } \\
\text { third molars } \\
\text { for } \\
\text { orthodontic } \\
\text { reasons }\end{array}$ & $\begin{array}{l}\text { Extraction of } \\
\text { periodontally } \\
\text { affected molar }\end{array}$ & $\begin{array}{l}\text { I-GMSCs } \\
\text { Inflammatory } \\
\text { cytokine- } \\
\text { treated } \\
\text { IGMSCs* }\end{array}$ & $\begin{array}{l}\text { I-DPSCs } \\
\text { Inf. cytokine- } \\
\text { treated } \\
\text { HDPSCs (in } \\
\text { some } \\
\text { experiment) }\end{array}$ & $\begin{array}{l}\text { H-GMSCS } \\
\text { H-DPSCs }\end{array}$ & Culture medium \\
\hline 8 & $\begin{array}{l}\text { Zhang et al., } \\
2017 \text { [35] }\end{array}$ & In vitro & Human & $\begin{array}{l}\text { Free gingival } \\
\text { collar }\end{array}$ & $\begin{array}{l}\text { Cells were treated } \\
\text { with IL- } 1 \beta \text {, TNF- } \alpha \text {, } \\
\text { and IFN- } \gamma\end{array}$ & $\begin{array}{c}\text { Inflammatory } \\
\text { cytokine- } \\
\text { treated H- } \\
\text { GMSCs }\end{array}$ & $\begin{array}{l}\text { Anti- } \\
\text { inflammatory } \\
\text { cytokine- } \\
\text { treated H- } \\
\text { GMSCs } \\
\end{array}$ & H-GMSCs & Culture medium \\
\hline 9 & $\begin{array}{c}\text { Jauregui et al., } \\
2018 \text { [33] }\end{array}$ & In vitro & Human & $\begin{array}{l}\text { Extraction of } \\
\text { impacted } \\
\text { third molars }\end{array}$ & $\begin{array}{l}\text { Flap and osseous } \\
\text { surgery in chronic } \\
\text { periodontitis }\end{array}$ & I-GMSCs & - & H-GMSCs & $\begin{array}{l}\text { Cells were seeded } \\
\text { on electrospun } \\
\text { polycaprolactone } \\
\text { scaffolds }\end{array}$ \\
\hline
\end{tabular}


TABLe 1: Continued.

\begin{tabular}{|c|c|c|c|c|c|c|c|c|c|}
\hline \multirow[b]{2}{*}{ No. } & \multirow[b]{2}{*}{ Study ID } & \multirow[b]{2}{*}{$\begin{array}{l}\text { Study } \\
\text { design }\end{array}$} & \multirow[b]{2}{*}{$\begin{array}{l}\text { GMSC } \\
\text { source }\end{array}$} & \multicolumn{2}{|c|}{ Sample collection } & \multicolumn{3}{|c|}{ Experimental design } & \multirow[b]{2}{*}{$\begin{array}{l}\text { Scaffold or carrier } \\
\text { (if present) }\end{array}$} \\
\hline & & & & Healthy & Diseased & $\begin{array}{l}\text { Source of } \\
\text { interest }\end{array}$ & $\begin{array}{l}\text { Other sources } \\
\text { (if present) }\end{array}$ & Control & \\
\hline 10 & $\begin{array}{l}\text { Soanca et al., } \\
2018 \text { [32] }\end{array}$ & In vitro & Human & $\begin{array}{l}\text { Teeth } \\
\text { extracted for } \\
\text { orthodontic } \\
\text { reasons }\end{array}$ & $\begin{array}{l}\text { Gingival associated } \\
\text { with overhanging } \\
\text { posterior } \\
\text { restoration }\end{array}$ & I-GMSCs & - & H-GMSCs & Culture medium \\
\hline 11 & $\begin{array}{c}\text { Yu et al., } 2019 \\
{[16]}\end{array}$ & $\begin{array}{l}\text { In vitro } \\
\text { \& in vivo }\end{array}$ & Mice & $\begin{array}{l}\text { Gingival } \\
\text { tissue from } \\
\text { maxillary } \\
\text { region }\end{array}$ & $\begin{array}{l}\text { Ligature-induced } \\
\text { periodontitis in } \\
\text { mice }\end{array}$ & I-GMSCs & - & H-GMSCs & $\begin{array}{c}\text { Systematic } \\
\text { transplantation of } \\
\text { stem cells (tail vein) } \\
\text { into dextran sulfate } \\
\text { sodium-induced } \\
\text { mouse colitis }\end{array}$ \\
\hline 12 & $\begin{array}{c}\text { Al-Bahrawy } \\
\text { et al., } 2020 \\
{[12]}\end{array}$ & In vitro & Human & $\begin{array}{c}\text { NS } \\
\text { Author } \\
\text { reported that } \\
\text { discarded } \\
\text { gingival } \\
\text { sample from } \\
\text { healthy } \\
\text { gingiva }\end{array}$ & $\begin{array}{l}\text { NS } \\
\text { Author reported } \\
\text { that discarded } \\
\text { gingival sample } \\
\text { from inflamed } \\
\text { gingiva }\end{array}$ & I-GMSCs & - & H-GMSCs & $\begin{array}{l}\text { Cells were seeded } \\
\text { on perforated } \\
\text { collagen-coated } \\
\text { poly-tetra-floro- } \\
\text { ethylene (PTFE) } \\
\text { membrane }\end{array}$ \\
\hline 13 & $\begin{array}{l}\text { Cristaldi et al., } \\
2020 \text { [13] }\end{array}$ & In vitro & Human & $\begin{array}{l}\text { Teeth } \\
\text { extracted for } \\
\text { orthodontic } \\
\text { reasons }\end{array}$ & $\begin{array}{l}\text { Extraction of } \\
\text { periodontally } \\
\text { affected teeth }\end{array}$ & I-GMSCs & - & H-GMSCs & $\begin{array}{l}\text { Cells were seeded } \\
\text { on Fisiograft Bone } \\
\text { Granular }^{\circledR} \text { and } \\
\text { Matriderm }^{\circledR} \\
\text { scaffolds }^{\text {and }}\end{array}$ \\
\hline
\end{tabular}

Despite the fact that I-GMSCs showed a decline in the osteogenic differentiation $[11,32]$, particularly after treatment with inflammatory cytokines [34], GMSCs had more resistance to inflammation-related changes in terms of osteogenic potential in vitro and bone formation in vivo compared to PDLSCs [11].

(2) Formation of Collagenous Tissue. Three of the included articles confirmed that the I-GMSCs formed a dense connective tissue similar to normal gingiva. Both inflamed and noninflamed sources generated dense collagenous connective tissue $[6,7,32]$. In particular, type 1 collagen $[6,32]$ and expression of intrinsic cytokines as matrix metallopeptidase1 and -2 (MMP-1 and -2), IL-1, IL-6, and TNF- $\alpha$ were more evident in I-GMSCs [34].

(3) Immunoregulation. Concerning the immunoregulation, two studies demonstrated this function. Both GMSC sources (inflamed and healthy) showed distinct immunoregulatory functions in the allograft mouse model through elevation of Tregs with comparison to BMSCs [6]. H-GMSCs expressed TLRs $1,2,3,4,5,6,7$, and 10, while GMSCs treated with inflammatory cytokines significantly expressed TLRs 1, 2, 4, 5, 7, and 10 without TLR 6 [15].

(4) Migration Capacity. Two of the selected studies reported that I-GMSCs migrated efficiently. No significant difference was observed between I-GMSCs and H-GMSCs, considering that IL-3 enhanced migration, motility, and wound closure; yet, BMSCs and ADSCs showed a higher expression of IL-
3R $\alpha$ than GMSCs [31]. Notably, H-GMSCs migrated better than I-GMSCs through large-pore membrane [12].

(5) Testing Biocompatibility of Resin Composite. The study by Soancă et al. [32] is the only study that assessed the behaviour of I-GMSCs in relation to some commercial resin dental composite. This study suggested that I-GMSCs can be used as a useful and valued cell line for testing dental materials (Table 2 and Figure 2).

3.5. Synthesis of Results. Since the current scoping review included outcome measures that vary considerably, we focused on describing the included studies qualitatively in terms of their results rather than meta-analysis.

\section{Discussion}

The purpose of the current study was to review the potential therapeutic role of inflamed gingiva-derived mesenchymal stem cells in preclinical studies and highlight their role in comparison to healthy gingiva or other MSC sources. The preclinical experiment is the basic building block of any novel therapeutic approach. The majority of in vitro included studies fulfilled items related to the presenting and interpreting the data and used appropriate statistical analysis. However, the methodological quality assessment revealed a lack of important items like sample size calculation, randomization, blinding, and explanation of any excluded data.

It is thought these items can be applied for clinical and in vivo studies, and they are not practical for in vitro studies. 


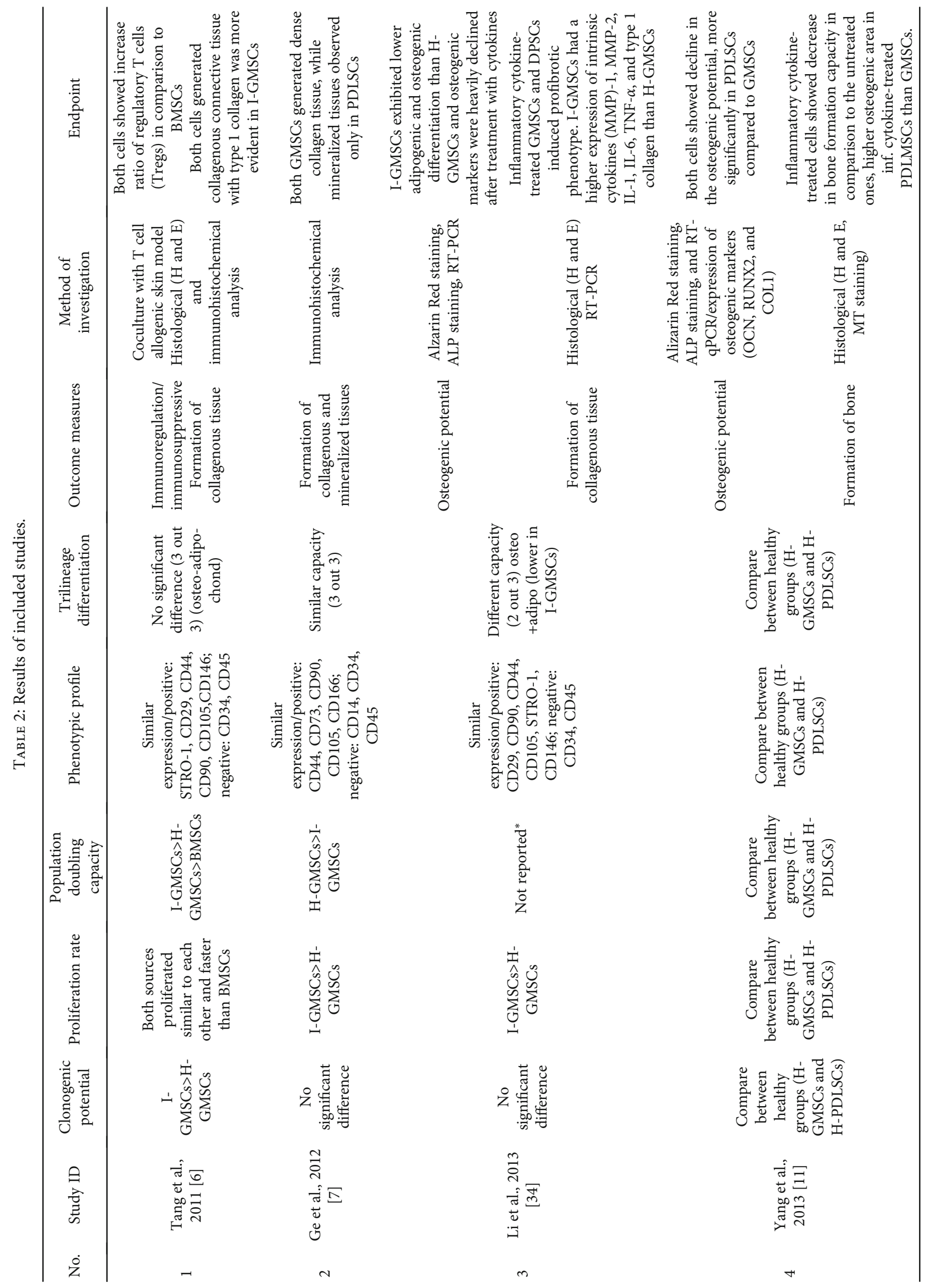




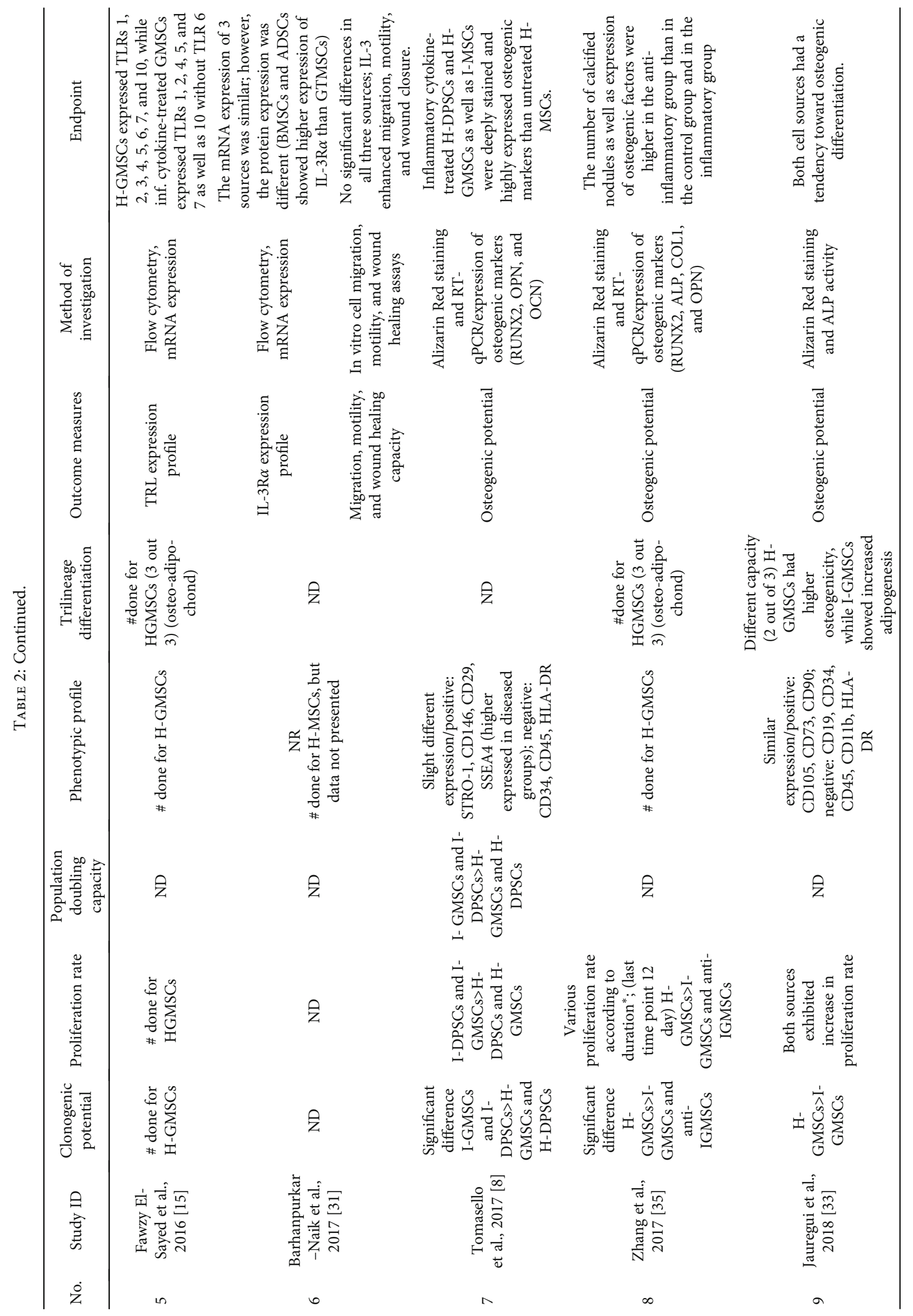




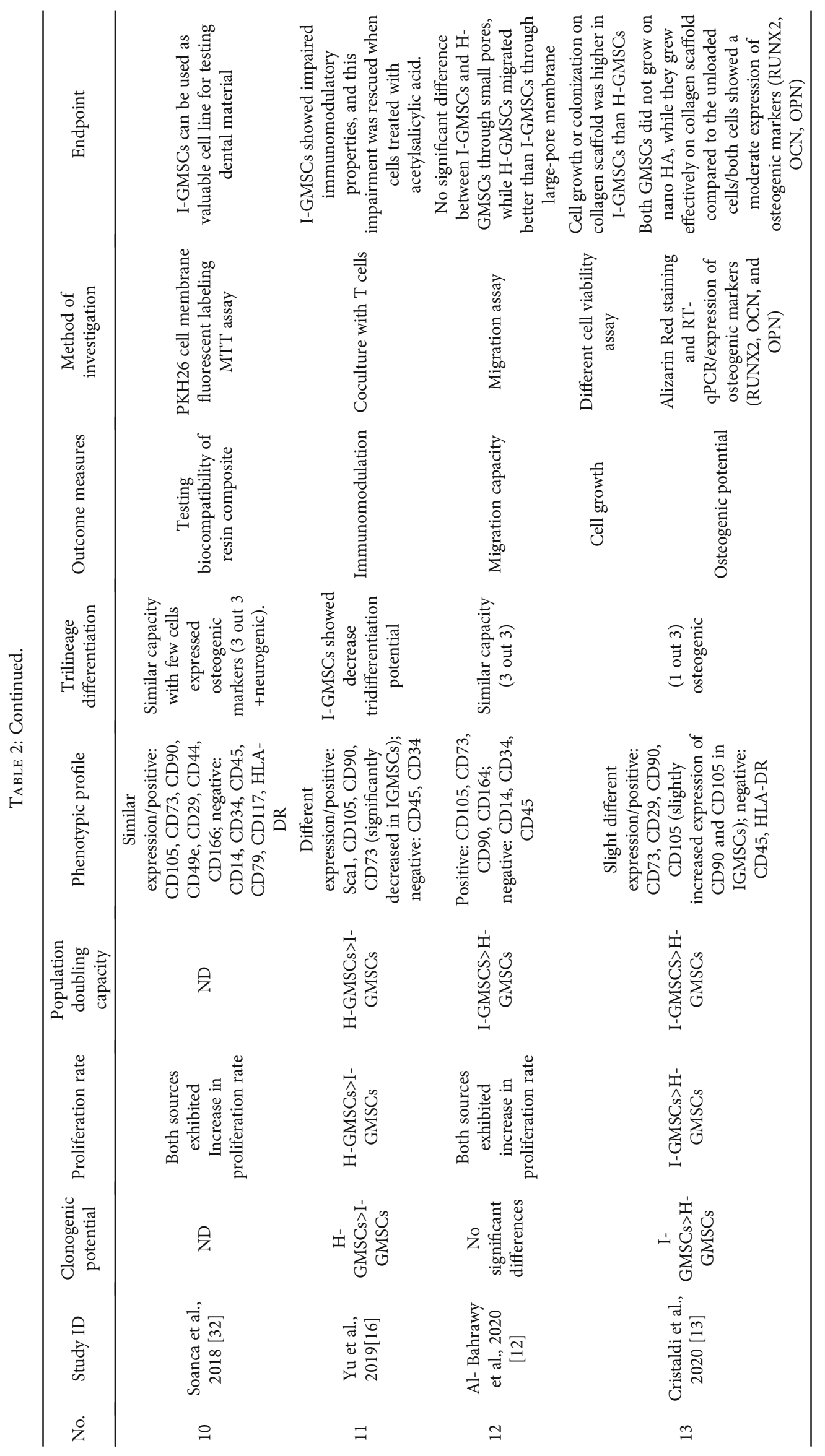




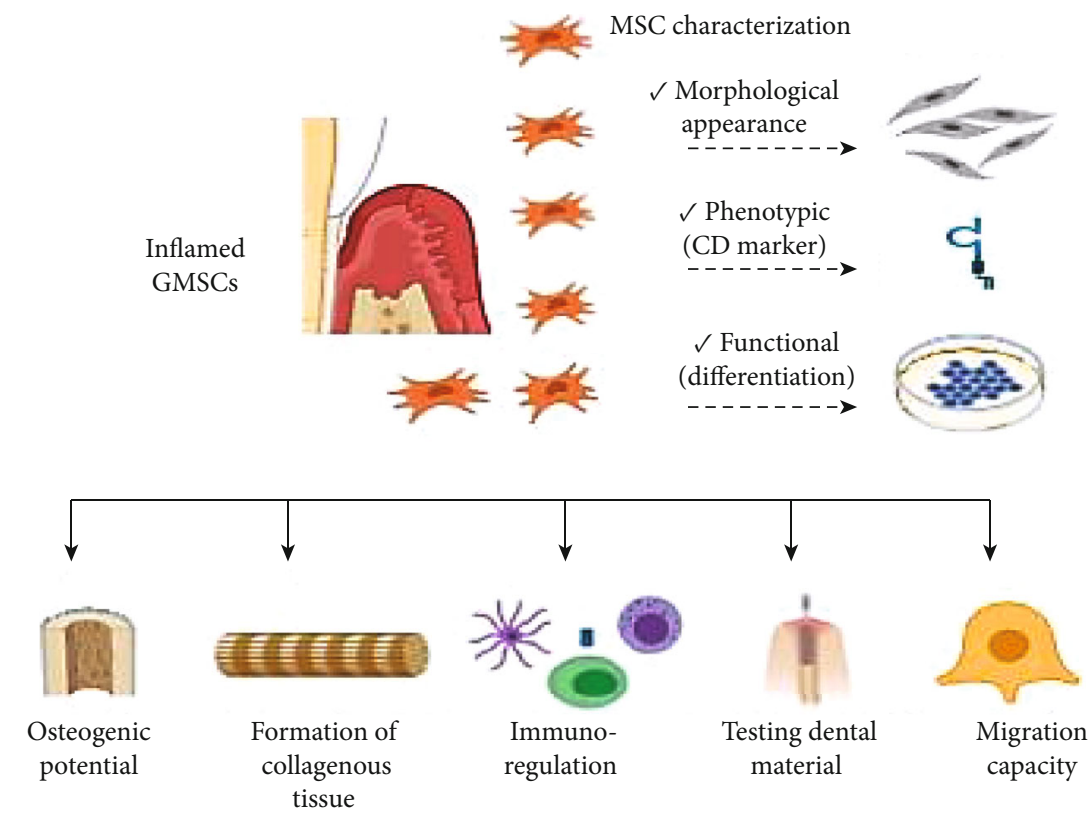

Greatrd in Biafandarcom bto

FIGURE 2: Possible applications and therapeutic roles of inflamed gingiva-derived mesenchymal stem cells.

Since many simple procedures should be added to design in vitro studies in order to reduce the bias, a well-designed in vitro experiment will positively affect their outcome and, in turn, their translation to in vivo and clinical applications. Randomization is essential for in vitro experiments because it deals with various issues that do not always have the same environment. For this reason, a culture flask or dish can be assigned at random to intervention and a column of wells in a multiwell plate may all be allocated to the same group. Thus, the column is considered as a single experimental unit, and the statistical analysis should be performed on the whole data from the whole column rather than on data from individual wells [23, 36]. Additionally, selecting fields for capturing histological or radiographical pictures should be done at random as well.

Before data processing, it might be useful to use a sample coding to blind the treatment category. Moreover, sample size can be estimated using either power analysis or the resource equation method, and the latter one is suitable in the case of in vitro studies where the absence of ethical issue and somewhat inexpensive experimental units so the upper limit can be increased [36]. The analysis of in vivo studies revealed several issues similar to the in vitro studies, namely, sample size, randomization, and blinding. In addition to that, all studies did not have enough and sufficient information about housing and husbandry conditions of animals, baseline data (characteristic and health status of animals), and an explanation of any excluded data. Determination of sample size is one of the important steps in designing animal studies; a fewer number of animals may lead to missing of any significant difference, and more number of animals selected may lead to misuse of resources and ethical problems [37].

Also, the standardization process is required to accurately evaluate the behaviour of cells. Recently, an innovative method using computer-aided design (CAD) technology was introduced to design a standardized sample culture plate model for in vitro studies to provide similar size and shape of scaffolds, to ensure optimum interaction between the seeded cells and these biomaterials and, in turn, to reduce bias in the measurements and results [38].

In respect of clonogenic, proliferation, and doubling population capacities, most of the selected studies indicate that there was no significant difference between I-GMSCs and HGMSCs; even the inflamed group was higher than the healthy one indicating that the inflamed condition could positively affect the regeneration potential of GMSCs. It has to be mentioned that not all included studies performed the previous assay so we present the available finding. Equally important, the majority of articles show that both I-GMSCs and HGMSCs display a positive expression of the principle MSC markers: STRO-1, CD29, CD44, CD90, CD105, and CD146 and negative expression of hematopoietic markers: CD34 and CD45. Both sources have the ability to differentiate into osteogenic, chondrogenic, and adipogenic lineage, while a minority of studies indicate that I-GMSCs have lower osteogenic and adipogenic differentiation capacity than the healthy groups. This finding is consistent with minimal criteria for MSCs proposed by the International Society for Cellular Therapy (ISCT) [39], so the resistance of GMSCs to inflammatory stimuli and maintaining their MSC features under inflammatory condition make them an attractive MSC source in tissue regenerative researches, where they could be subjected to similar inflammatory microenvironment [17].

Overall, the osteogenic potential and formation of collagenous tissues are confirmed by histological, immunohistochemical, and gene expressions. The most common methods used to evaluate the osteogenic potential of included 
studies are Alizarin Red staining, Haematoxylin and Eosin (H\&E) staining, and the expression of osteogenic markers (RUNX2, ALP, OCN, and OPN). The immunohistochemical analysis used to assess the collagenous tissue formation has been reported by the studies conducted by Tang et al. and Ge et al. [6, 7]. In one study, H-GMSCs had higher osteogenicity, while I-GMSCs showed increased adipogenesis and this is maybe accounted for the difference in epigenetic factors that are associated with chronic periodontitis and affect the differential directions of these cell lines [33]. Several included studies confirmed that osteoblastic differentiation capacity under proinflammatory treated culture was significantly higher than uninduced cultures and almost equal to periodontally affected MSCs. It has been known that proinflammatory mediators such as IL- $1 \beta$ and TNF- $\alpha$ play a crucial role in activating intracellular pathways required in cellular viability, proliferation, and differentiation toward certain cell lines. For instance, TNF- $\alpha$ induces the osteogenic differentiation of DPSCs by activation of the NF- $\kappa$ B pathway $[31,40]$.

Besides, the inflammatory microenvironment activates cytoskeletal remodeling via interaction between high levels of chaperone proteins like heat shock protein 90 (hsp90), thioredoxin-1 (TXN-1), and heat shock protein A9 (hspA9) and actin filaments like cofilin, profiling, and vinculin, leading to stabilize actin filaments, and this interaction is closely related to the differentiation process [8]. Although the existence of an inflammatory state led to a decrease in the osteogenic differentiation in some studies [11, 32], GMSCs exhibited more resistance to inflammation-related changes compared to PDLSCs [11].

PDLSCs, on the other hand, have limited cell availability and reduced therapeutic viability, whereas gingival tissue is relatively abundant and easily accessible. Further, both MSCs from inflamed and noninflamed gingival tissues generated dense collagenous connective tissue resembles the natural gingiva $[6,7,32]$, with type 1 collagen $[6,32]$, and expression of intrinsic cytokines MMP-1, MMP-2, IL-1, IL-6, and TNF$\alpha$ were more evident in I-GMSCs [34]. Cross talk between GMSCs, extracellular matrix, inflammatory mediators, and inflammatory cells induce the profibrotic phenotype of cells.

A class of sensor proteins known as TLRs mediates recognition of PAMPs and initiation of inflammation as well as immune responses. Microbial products stimulate TLRs and lead to the activation of signaling pathways that result in the induction of antimicrobial genes and inflammatory cytokines. In addition to their expression in immune cells (e.g., dendritic cells and macrophages) and nonimmune cells (e.g., fibroblast and epithelial cells), several TLRs are expressed in MSCs and contribute to the protection against infection. Based on MSC origin, an inflammatory condition may modulate the pattern and role of TLRs expressed by MSCs [41, 42]. Among these MSCs, I-GMSCs highly express TLRs $1,2,4,5,7$, and 10, enhancing the capacity of G-MSCs to recognize in vivo periodontal PAMPs [15].

Notably, H-GMSCs have the ability to ameliorate inflammation in a colitis experimental model, and I-GMSCs improve subcutaneous transplantation of murine skin allografts via activation or generation of infiltrating regulatory $\mathrm{T}$ cells $[3,6]$. These may be attributed to highly conserved cross-species effects of cytokines, mediating the immunoregulatory effects of MSC or maybe due to the production of IL10 and indoleamine 2,3-dioxygenase (IDO), which mediate immunoregulation $[3,6]$.

The migration of MSCs toward the damaged tissue is an important step in tissue regeneration. Concerning the migration capacity in the healthy and inflamed groups, there was no significant difference in the number of migrated GMSCs across different membrane micropore sizes, except for large sizes, where H-GMSCs displayed a higher migratory dynamic. This finding is related to developing selective driven membranes for tissue regeneration, particularly for periodontal regeneration, which enable stem cells to migrate through the scaffold [12]. IL-3 significantly enhances the migration, motility, and wound healing abilities of MSCs, including I-GMSCs, by upregulating the expression of chemokine receptors (CXCR4). Moreover, IL-3-induced CXCR4 expression leads to increased migration of MSCs towards SDF-1 $\alpha$, enhancing the migration and homing efficiency of MSCs [31].

Culture condition is one of the most essential factors in controlling MSC homing and migration efficiency: proinflammatory cytokines TGF- $\beta 1$, IL- $1 \beta$, and TNF- $\alpha$ facilitated BMSC migration across reconstituted human basement membranes by increasing production of MMP-2, MT1MMP, and/or MMP-9 in these cells. This in vitro result provides a potential mechanism in MSC recruitment and migration toward the damaged tissue in vivo [43].

Lastly, I-GMSCs can be used as a useful and valued cell line for testing resin composite dental material due to the proximity of dental material to gingival tissue, and the standard cytotoxicity tests cannot predict in vivo behaviour of commercial materials. So, it is a good idea to determine the biocompatibility of dental materials at the cellular level using discarded human cell lines rather than animal lines [32].

\section{Limitations}

Included studies did not perform enough in vitro MSC characterization of cells derived from the inflamed tissue. Also, the lack of consistency between in vitro and subsequent in vivo study (ectopic formation) in the same article constituted another limitation in some studies.

\section{Conclusion}

The gingiva represents the easiest and most accessible MSC source in the oral cavity. Inflamed gingiva-derived MSCs are considered a unique biomedical waste as they retain their viability, morphology, phenotypic, and functional features of MSCs under inflammatory conditions. In addition to this, the inflammatory microenvironment promoted migration capacity and motility of GMSCs. Since the existence of an inflammatory microenvironment does not negatively affect MSC characterization, I-GMSCs could be used in experiments that involved diseases with persistent inflammatory conditions. In preclinical studies, I-GMSCs showed a colony formation ability similar or even more than healthy ones and a proliferation capacity faster than control groups. Besides, I-GMSCs could be a promising source in the following aspects: osteogenic differentiation, 
collagen fiber formation, immunoregulation, and testing of dental materials. Even though I-GMSCs represent a new therapeutic solution and could be a viable alternative source to H-GMSCs for tissue regeneration purposes, further and well-designed preclinical studies are required to confirm the previous findings and to determine the feasibility of this source. Equally important, the authors should follow the standard guideline as much as possible to reduce bias and gaps between preclinical searches and clinical use.

\section{Abbreviations}

$\begin{array}{ll}\text { ADSCs: } & \text { Adipose-derived stem cells } \\ \text { ALP: } & \text { Alkaline phosphatase } \\ \text { ASA: } & \text { Acetylsalicylic acid } \\ \text { BMSCs: } & \text { Bone marrow mesenchymal stem cells } \\ \text { CFU: } & \text { Colony-forming units } \\ \text { COL1: } & \text { Collagen type 1 } \\ \text { CXCR: } & \text { Chemokine receptor } \\ \text { DPSCs: } & \text { Dental pulp stem cells } \\ \text { FASL: } & \text { Fas Ligand } \\ \text { GMSCs: } & \text { Gingival mesenchymal stem cells } \\ \text { HA: } & \text { Hydroxyapatite } \\ \text { H-GMSCs: } & \text { Healthy gingiva-derived mesenchymal stem } \\ & \text { cells } \\ \text { hsp: } & \text { Heat shock protein } \\ \text { IDO: } & \text { Indoleamine 2,3-dioxygenase } \\ \text { IFN- } \gamma: & \text { Interferon- } \gamma \\ \text { I-GMSCs: } & \text { Inflamed gingiva-derived mesenchymal stem } \\ & \text { cells } \\ \text { IL-1 } \beta: & \text { Interleukin-1 } \beta \\ \text { ISCT: } & \text { International Society for Cellular Therapy } \\ \text { MMP: } & \text { Matrix metallopeptidase } \\ \text { MSCs: } & \text { Mesenchymal stem cells } \\ \text { NSAID: } & \text { Nonsteroidal anti-inflammatory drug } \\ \text { OCN: } & \text { Osteocalcin } \\ \text { OPN: } & \text { Osteopontin } \\ \text { PAMPs: } & \text { Pathogen-associated molecular patterns } \\ \text { PDLSCs: } & \text { Periodontal ligament mesenchymal stem cells } \\ \text { RUNX2: } & \text { Runt-related transcription factor } 2 \\ \text { TLRs: } & \text { Toll-like receptors } \\ \text { TNF- } \alpha: & \text { Tumor necrosis factor- } \alpha \\ \text { Tregs: } & \text { Regulatory T cells } \\ \text { TXN-1: } & \text { Thioredoxin-1. } \\ & \end{array}$

\section{Conflicts of Interest}

The authors declare that they have no conflicts of interest.

\section{Supplementary Materials}

Supplementary material I: the quality of the in vitro and in vivo studies selected in this scoping review. (Supplementary Materials)

\section{References}

[1] A. Ballini, S. Cantore, S. Scacco, D. Coletti, and M. Tatullo, "Mesenchymal stem cells as promoters, enhancers, and play- makers of the translational regenerative medicine 2018," Stem Cells International, vol. 2018, 2 pages, 2018.

[2] G. Spagnuolo, B. Codispoti, M. Marrelli, C. Rengo, S. Rengo, and M. Tatullo, "Commitment of oral-derived stem cells in dental and maxillofacial applications," Dental Journal, vol. 6, no. 4, pp. 72-78, 2018.

[3] Q. Zhang, S. Shi, Y. Liu et al., "Mesenchymal stem cells derived from human gingiva are capable of immunomodulatory functions and ameliorate inflammation-related tissue destruction in experimental colitis," Journal of Immunology, vol. 183, no. 12, pp. 7787-7798, 2009.

[4] B. P. J. Fournier, F. C. Ferre, L. Couty et al., "Multipotent progenitor cells in gingival connective tissue," Tissue Engineering Part A, vol. 16, no. 9, pp. 2891-2899, 2010.

[5] N. Mensing, H. Gasse, N. Hambruch, J. D. Haeger, C. Pfarrer, and C. Staszyk, "Isolation and characterization of multipotent mesenchymal stromal cells from the gingiva and the periodontal ligament of the horse," BMC Veterinary Research, vol. 7, no. 1, p. 42, 2011.

[6] L. Tang, N. Li, H. Xie, and Y. Jin, "Characterization of mesenchymal stem cells from human normal and hyperplastic gingiva," Journal of Cellular Physiology, vol. 226, no. 3, pp. 832-842, 2011.

[7] S. Ge, K. M. Mrozik, D. Menicanin, S. Gronthos, and P. M. Bartold, "Isolation and characterization of mesenchymal stem cell-like cells from healthy and inflamed gingival tissue: potential use for clinical therapy," Regenerative Medicine, vol. 7, no. 6, pp. 819-832, 2012.

[8] L. Tomasello, R. Mauceri, A. Coppola et al., "Mesenchymal stem cells derived from inflamed dental pulpal and gingival tissue: a potential application for bone formation," Stem Cell Research \& Therapy, vol. 8, no. 1, p. 179, 2017.

[9] S. Santamaría, N. Sanchez, M. Sanz, and J. A. Garcia-Sanz, "Comparison of periodontal ligament and gingiva-derived mesenchymal stem cells for regenerative therapies," Clinical Oral Investigations, vol. 21, no. 4, pp. 1095-1102, 2017.

[10] D. Liu, J. Xu, O. Liu et al., "Mesenchymal stem cells derived from inflamed periodontal ligaments exhibit impaired immunomodulation," Journal of Clinical Periodontology, vol. 39, no. 12, pp. 1174-1182, 2012.

[11] H. Yang, L. Gao, Y. An et al., "Comparison of mesenchymal stem cells derived from gingival tissue and periodontal ligament in different incubation conditions," Biomaterials, vol. 34, no. 29, pp. 7033-7047, 2013.

[12] M. Al Bahrawy, K. Ghaffar, A. Gamal, K. El-Sayed, and V. Iacono, "Effect of inflammation on gingival mesenchymal stem/progenitor cells' proliferation and migration through microperforated membranes: an in vitro study," Stem Cells International, vol. 2020, Article ID 5373418, 10 pages, 2020.

[13] M. Cristaldi, R. Mauceri, G. Campisi et al., "Growth and osteogenic differentiation of discarded gingiva-derived mesenchymal stem cells on a commercial scaffold," Frontiers in Cell and Development Biology, vol. 8, 2020.

[14] Q.-Z. Zhang, W.-R. Su, S.-H. Shi et al., "Human gingivaderived mesenchymal Stem Cells Elicit Polarization of M2 Macrophages and enhance cutaneous wound healing," Stem Cells, vol. 28, no. 10, pp. 1856-1868, 2010.

[15] K. Fawzy-El-Sayed, M. Mekhemar, S. Adam-Klages, D. Kabelitz, and C. Dörfer, "TLR expression profile of human gingival margin-derived stem progenitor cells," Medicina Oral, Patología Oral y Cirugía Bucal, vol. 21, no. 1, pp. e30-e38, 2016. 
[16] T. Yu, B. Yan, J. Li et al., "Acetylsalicylic acid rescues the immunomodulation of inflamed gingiva-derived mesenchymal stem cells via upregulating FasL in mice," Stem Cell Research \& Therapy, vol. 10, no. 1, p. 368, 2019.

[17] K. M. Fawzy el-Sayed and C. Dörfer, "Gingival mesenchymal stem/progenitor cells: a unique tissue engineering gem," Stem Cells International, vol. 2016, 16 pages, 2016.

[18] A. Cekici, A. Kantarci, H. Hasturk, and T. E. Van Dyke, "periodontal disease,” Periodontology 2000, vol. 6, no. 3, pp. 165$166,1961$.

[19] S. Cantore, A. Ballini, G. Mori et al., "Anti-plaque and antimicrobial efficiency of different oral rinses in a 3-day plaque accumulation model," Journal of Biological Regulators and Homeostatic Agents, vol. 30, no. 4, pp. 1173-1178, 2016.

[20] I. S. Song, J. E. Lee, and J. B. Park, "The effects of various mouthwashes on osteoblast precursor cells," Open Life Sciences, vol. 14, no. 1, pp. 376-383, 2019.

[21] M. Tatullo, B. Codispoti, A. Pacifici et al., "Potential use of human periapical cyst-mesenchymal stem cells (hPCy-MSCs) as a novel stem cell source for regenerative medicine applications," Frontiers in Cell and Development Biology, vol. 5, 2017.

[22] A. C. Tricco, E. Lillie, W. Zarin et al., "PRISMA extension for scoping reviews (PRISMA-ScR): checklist and explanation," Annals of Internal Medicine, vol. 169, no. 7, pp. 467-473, 2018.

[23] C. M. Faggion, "Guidelines for reporting pre-clinical in vitro studies on dental materials," The Journal of Evidence-Based Dental Practice, vol. 12, no. 4, pp. 182-189, 2012.

[24] C. Kilkenny, W. Browne, I. C. Cuthill, M. Emerson, and D. G. Altman, "Animal research: Reportingin vivoExperiments-The ARRIVE guidelines," Journal of Cerebral Blood Flow and Metabolism, vol. 31, no. 4, pp. 991-993, 2011.

[25] M. K. Mekhemar, S. Adam-Klages, D. Kabelitz, C. E. Dörfer, and K. M. Fawzy El-Sayed, "TLR-induced immunomodulatory cytokine expression by human gingival stem/progenitor cells," Cellular Immunology, vol. 326, pp. 60-67, 2018.

[26] C. Giacomelli, L. Natali, M. Nisi et al., "Negative effects of a high tumour necrosis factor- $\alpha$ concentration on human gingival mesenchymal stem cell trophism: the use of natural compounds as modulatory agents," Stem Cell Research \& Therapy, vol. 9, no. 1, p. 135, 2018.

[27] R. Wang, Q. Ji, C. Meng et al., "Role of gingival mesenchymal stem cell exosomes in macrophage polarization under inflammatory conditions," International Immunopharmacology, vol. 81, article 106030, 2020.

[28] Q. Li, F. Liu, R. Dang et al., "Epigenetic modifier trichostatin A enhanced osteogenic differentiation of mesenchymal stem cells by inhibiting NF- $\kappa$ B (p65) DNA binding and promoted periodontal repair in rats," Journal of Cellular Physiology, vol. 235, no. 12, pp. 9691-9701, 2020.

[29] K. M. Fawzy el-Sayed, D. Hein, and C. Dörfer, "Retinol/inflammation affect stemness and differentiation potential of gingival stem/progenitor cells via Wnt/ $\beta$-catenin," Journal of Periodontal Research, vol. 54, no. 4, pp. 413-423, 2019.

[30] Y. Luo, W. Wu, J. Gu et al., "Human gingival tissue-derived MSC suppress osteoclastogenesis and bone erosion via CD39-adenosine signal pathway in autoimmune arthritis," eBioMedicine, vol. 43, pp. 620-631, 2019.

[31] A. Barhanpurkar-Naik, S. T. Mhaske, S. T. Pote, K. Singh, and M. R. Wani, "Interleukin-3 enhances the migration of human mesenchymal stem cells by regulating expression of CXCR4," Stem Cell Research \& Therapy, vol. 8, no. 1, p. 168, 2017.
[32] A. Soancă, M. Lupse, M. Moldovan et al., "Applications of inflammation-derived gingival stem cells for testing the biocompatibility of dental restorative biomaterials," Annals of Anatomy, vol. 218, pp. 28-39, 2018.

[33] C. Jauregui, S. Yoganarasimha, and P. Madurantakam, "Mesenchymal stem cells derived from healthy and diseased human gingiva support osteogenesis on electrospun polycaprolactone scaffolds," Bioengineering, vol. 5, no. 1, p. 8, 2018.

[34] N. Li, J. Zhou, L. Tang et al., "Inflammatory environment induces gingival tissue-specific mesenchymal stem cells to differentiate towards a pro-fibrotic phenotype," Biology of the Cell, vol. 105, no. 6, pp. 261-275, 2013.

[35] F. Zhang, M. Si, H. Wang, M. K. Mekhemar, C. E. Dörfer, and K. M. Fawzy El-Sayed, "IL-1/TNF- $\alpha$ inflammatory and antiinflammatory synchronization affects gingival stem/progenitor cells' regenerative attributes," Stem Cells International, vol. 2017, 9 pages, 2017.

[36] M. F. W. Festing, O. Box, and L. Road, "Guidelines for the design and statistical analysis of experiments in papers submitted to ATLA," Alternatives to Laboratory Animals, vol. 29, no. 4, pp. 427-446, 2001.

[37] J. Charan and N. Kantharia, "How to calculate sample size in animal studies ?," Journal of Pharmacology and Pharmacotherapeutics, vol. 4, no. 4, pp. 303-306, 2013.

[38] M. Marrelli, A. Pujia, F. Palmieri et al., "Innovative approach for the in vitro research on biomedical scaffolds designed and customized with CAD-CAM technology," International Journal of Immunopathology and Pharmacology, vol. 29, no. 4, pp. 778-783, 2016.

[39] M. Dominici, K. le Blanc, I. Mueller et al., "Minimal criteria for defining multipotent mesenchymal stromal cells. The International Society for Cellular Therapy position statement," Cytotherapy, vol. 8, no. 4, pp. 315-317, 2006.

[40] X. Feng, G. Feng, J. Xing et al., "TNF- $\alpha$ triggers osteogenic differentiation of human dental pulp stem cells via the NF- $\kappa$ B signalling pathway," Cell Biology International, vol. 37, no. 12, pp. 1267-1275, 2013.

[41] M. Najar, M. Krayem, N. Meuleman, D. Bron, and L. Lagneaux, "Mesenchymal stromal cells and toll-like receptor priming : a critical review," Immune Network, vol. 17, no. 2, pp. 89-102, 2017.

[42] C. A. Janeway and R. Medzhitov, "INNATEIMMUNERECOGNITION," Annual Review of Immunology, vol. 20, no. 1, pp. 197-216, 2002.

[43] C. Ries, V. Egea, M. Karow, H. Kolb, M. Jochum, and P. Neth, "MMP-2 , MT1-MMP, and TIMP-2 are essential for the invasive capacity of human mesenchymal stem cells : differential regulation by inflammatory cytokines," Blood, vol. 109, no. 9, pp. 4055-4063, 2007. 